удК 330

\title{
РОЗВИТОК СОЦІАЛЬНОГО ПІДПРИЄМНИЦТВА В УКРАЇНІ ТА ЗАРУБІЖНИХ КРАЇНАХ ПІД ВПЛИВОМ КРИЗИ, СПРИЧИНЕНОÏ ПАНДЕМІЄЮ COVID-19
}

\section{EVELOPMENT OF SOCIAL ENTREPRENEURSHIP IN UKRAINE AND FOREIGN COUNTRIES BASED ON THE INFLUENCE OF THE CRISIS CAUSED BY THE COVID-19 PANDEMIC}

\author{
Дзюба Оксана Миколаївна \\ кандидат економічних наук, доцент, \\ Національний транспортний університет \\ ORCID: https://orcid.org/0000-0002-2411-5844 \\ Берідзе Ксенія Тенгізівна \\ аспірант, \\ Національний транспортний університет \\ ORCID: https://orcid.org/0000-0002-7482-9132 \\ Dziuba Oksana, Beridze Kseniia \\ National Transport University
}

\begin{abstract}
Стаття присвячена актуальним питанням розвитку соціального підприємництва під впливом кризи спричиненої пандемією COVID-19 та наслідкам впливу кризи на діяльність соціальних підприємств, підтримці соціального підприємництва на державному рівні в Україні та зарубіжних країнах. Пандемія COVID-19 стала значним випробовуванням для кожної країни щодо спроможності її державного апарату впоратись із викликами, спричиненими нею як для медичної системи, так і для економічного сектору. Україна, як і інші країни ЄС, 3 метою запобігання поширення коронавірусної інфекції, прийняла рішення щодо введення жорстких карантинних ще на початку весни 2020. А у цих умовах українські соціальні підприємства, діяльність яких здебільшого підпадає під зазначені категорії заборон, опинились в критичній ситуації.

Ключові слова: соціальні підприємництво, пандемія, підприємство, розвиток, бізнес-моделі.
\end{abstract}

Статья посвящена актуальным вопросам развития социального предпринимательства, под воздействием кризиса вызванного пандемией COVID-19 и последствиям влияния кризиса на деятельность социальных предприятий, поддержке социального предпринимательства на государственном уровне в Украине и зарубежных странах. Пандемия COVID-19 стала значительным испытанием для каждой страны относительно способности ее государственного аппарата справиться с вызовами, вызванными ею как для медицинской системы, так и для экономического сектору. Украина, как и другие страны ЕС, с целью предотвращения распространения коронавірусної инфекции приняла решение относительно введения жестких карантинных еще в начале весны 2020. В этих условиях украинские социальные предприятия, деятельность которых по большей части подпадает под отмеченные категории запретов, оказались в критической ситуации.

Ключевые слова: социальны предпринимательство, пандемия, предприятие, развитие, бизнес-модели.

The relevance of this article is primarily related to the development of social entrepreneurship under the influence of the crisis caused by the COVID-19 pandemic and the effects of the crisis on the activities of social enterprises, support for social entrepreneurship at the state level in Ukraine and in foreign countries. The purpose of the article is to consider the functioning of social enterprises during a pandemic, to identify problematic aspects and possible directions of development of social entrepreneurship in Ukraine during a pandemic. According to the World Bank, the global economy fell by $4.3 \%$ last year, the pandemic resulted in casualties and population, and millions of people were in trouble. Social innovators, disruptors in the service of others in situations where traditional actors or the market have failed, are needed more than ever in the current COVID-19 pandemic. This is especially true as the health and economic impacts hit the excluded, vulnerable and those in the informal economy the hardest. The COVID-19 
pandemic came as a surprise to the world, and each country has questions about the ability of its government to meet the challenges it faces in all walks of life. At the beginning of the pandemic, fist of all there were disruptions and delays in the schedule of deliveries and deliveries of workers to the workplace, as the government developed measures to curb the spread of the virus worldwide. The consequences of quarantine have a long-term effect, so the resumption of work in some enterprises is still happening. Many social enterprises have changed their business models to ensure the fulfillment of orders and the provision of services over the Internet. As a result, digitalization has become the key to business continuity. Following the pandemic, small and medium-sized businesses are likely to be divided into two types: business and e-commerce. In times like these, we need social innovators even more - s they are already embedded and empower communities and are responsive with solutions - an d they are adapting to the immediate needs of the people they serve. The practical value of the study is that its results can be used to study the work of the social enterprise during the quarantine restrictions caused by the COVID-19 pandemic.

Keywords: an enterprise, pandemic, enterprise, development, model business, is social.

Постановка проблеми. Криза, спричинена пандемією COVID-19, значно вплинула на діяльність соціальних підприємців та підприємниць та пригальмувала розвиток соціального підприємництва в Україні загалом. Більшість соціальних підприємств були вимушені переглянути свої бізнес моделі, а деяким довелось призупинити свою діяльність. Хоча державою і було запроваджено певні точкові механізми підтримки суб'єктів малого та середнього бізнесу, респонденти та респондентки проведених опитувань не розраховують на державну підтримку оскільки для деяких із них вона не є доступною, а де решти - занадто ризиковою. Тож у питанні подолання наслідків кризи вони орієнтуються на власні можливості та підтримку міжнародних донорів.

Аналіз досліджень і публікацій. Дослідниками, які вивчають проблеми сучасного соціального підприємництва в Україні та світовий досвід $€$ : 3. Галушка, А. Корнецький, О. Кіреєва, А. Курило, Е. Немкович, О. Овсянюк-Бернадіна, Ж. Крисько, М. Куц, А. Мокій, М. Наумова, І. Салій, О. Сандакова та інші.

Виділення невирішених раніше частин загальної проблеми. Проаналізувати процеси становлення і функціонування соціальних підприємств під впливом пандемії, виявити проблемні аспекти фрункціонування та можливі напрями розвитку соціального підприємництва в Україні під час пандемії.

Викладення основного матеріалу та об'рунтування отриманих результатів дослідження. Каталог соціальних підприємств України 2016-2017 було сфрормовано у 2016 році саме тоді було проведено останній перепис соціальних підприємств. Це другий каталог соціальних підприємств у якому зібрано, систематизовано та представлено в алфравітному порядку інформацію про 150 соціальних підприємств України, 3 яких 91 своєю основною діяльністю визначають працевлаштування уразливих груп населення (людей $з$ інвалідністю, ветеранів та ветеранок АТО, внутрішньо переміщених осіб), 79 генерують прибуток для підтримки діяльності організації, 60 генерують прибутки для надання послуг конкретним групам населення, а 40 фрінансують певні види послуг. Перший Каталог соціальних підприємств України 2013 року містив інсрормацію лише про 41 соціальне підприємство. Після 2017 перепис і підрахунок соціальних підприємств не проводився.

Певну інорормацію щодо соціальних підприємств можна знайти на інформаційному pecypci «Social business in UA» - він нараховує 52 соціальні підприємства. Проте за даними аналітичного звіту «Соціальне підприємництво в Україні: Економіко-правовий аналіз», аналітичний звіт був підготовлений групою експертів у галузі права, економіки та соціально-політичних наук для проекту «EU4Youth - Розкриття потенціалу молодих соціальних підприємців в Молдові та Україні» у 2020 році сьогодні в Україні працюють близько 1000 підприємств, які можна віднести до соціальних, що демонструє прогресуючий зріст кількості соціальних підприємств у останні 6 років, проте інорормацію про них фррагментарна та розрізнена.

Незважаючи на те, що офріційного перепису соціальних підприємств в Україні підготовленого у 2020 році немає, проблеми, які стоять на шляху розвитку соціального підприємництва в Україні залишаються незмінними. Найголовніша, на нашу думку, проблема полягає у відсутності законодавчого визначення поняття соціальне підприємство та регулювання діяльності у результаті чого в Україні також відсутні офріційні статистичні дані щодо кількості соціальних підприємств та обсягів їх підприємницької діяльності. Також вагомою проблемою для діяльності соціальних підприємств в Україні $€$ недостатня підтримка держави, а саме відсутність програм з допомоги у розвитку або ж фрінансування цього виду 
підприємство, звідки виникає залежність соціальних підприємств від інвестицій, іноземної підтримки.

11 березня набрала чинності Постанова Кабінету Міністрів України «Про запобігання поширенню на території України гострої респіраторної хвороби COVID-19, спричиненої коронавірусом SARS-CoV-2» № 211 від 11.03.2020, якою на всій території України встановлювали карантин з 12 березня 2020 до 3 квітня 2020, а діяльність соціальних підприємств здебільшого підпадає під першу та другу категорії заборон. Карантинні обмеження в Україні весь час зазнавали певних трансорормацій, усі підприємства вимушені були адаптувати свій грасрік роботи до нових умов, деякі із них перевели співробітників та співробітниць на роботу у фрорматі неповного робочого дня, а деякі одразу запровадили дистанційний режим. Отже, постала гостра необхідність у адаптування та перегляді бізнес-моделі більшості соціальних підприємств.

За даними другий каталог соціальних підприємств в Україні вони фрункціонують як мікро або малий бізнес зі штатом до 5 осіб. Підприємства такого масштабу можуть швидше адаптуватися до нових карантинних змін та оптимізувати свої виробничі процеси [2].

Опитування соціальних підприємців та підприємниць, яке було здійснено у межах дослідження для проєкту «Соціальне підприємництво в Україні в часи COVID-19 через призму гендерної рівності», відбулось у червні-липні 2020. Соціальні підприємці та підприємниці наголошували на факті падіння купівельної спроможності клієнтів та клієнток на ринку, а також зміні їх споживацької поведінки та пріоритетів у прийнятті рішення щодо купівлі тих чи інших товарів. Велике значення наразі має безпечність процесу здійснення покупки, можливість здійснення замовлення онлайн та отримання доставки безконтактно. Про скорочення кількості клієнтів та клієнток повідомили $62,8 \%$ опитаних соціальних підприємців та підприємниць, у той час як зростання їхньої кількості мало місце лише для 9,8\% підприємств [9].

Також лише четверта частина соціальних підприємців та підприємниць працювала над розвитком діджитал-маркетингу (налагодженням продажів через сайт, Instagram, Facebook, email) до початку пандемії COVID-19. У перший місяць карантину тільки п'ять 3 опитаних соціальних підприємств переробили свій веб-сайт та додали нові послуги і сервіси. Наприклад, команда соціального під- приємства музею «Третя після опівночі», що працевлаштовує незрячих людей, з першого тижня карантину почала шукати додаткові джерела фрінансування для оплати орендованого приміщення. Спершу вони додали можливість придбання брендованих речей у онлайн-крамничці на сайті та можливість придбання «підвішеної екскурсії» - сертифрікату для здійснення екскурсії у майбутньому, після чого створили опцію аудіо-екскурсії музеєм, а згодом розробили освітній онлайн-квест для дітей 3 розвитку п'яти відчуттів, який також проводять незрячі гіди. На завершення, поки жителям та жителькам Києва було заборонено відвідувати екскурсії в класичних музеях в приміщеннях, музей «Третя після опівночі» вийшов за рамки і запропонував новий формат екскурсій під назвою «Київ на осліп». Він передбачає прогулянку Києвом із заплющеними очима у супроводі незрячого гіда. Тож, незважаючи на усі виклики, пандемія стала для музею стимулом до впровадження додаткових фрорматів роботи та розробки нових товарів та послуг [9].

Нижче зазначені найвагоміші, на думку респондентів та респонденток опитувань, наслідки впливу кризи, спричиненої COVID-19, на діяльність соціальних підприємств:

1. Поява додаткових витрат.

2. Поява проблем з виплатою заробітної платні та скороченням штату.

3. Поява проблем 3 логістикою та транспортуванням співробітників та співробітниць підприємств на роботу.

4. Поява проблем зі здійснення орендних платежів.

5. Поява проблем з постачанням сировини.

6. Поява проблем зі збутом товарів.

7. Поява проблем з відсутністю обігових коштів [9].

На жаль, так як соціальне підприємство в Україні немає чіткого законодавчого регулювання, підтримка на державному рівні здійснюється виключно у межах підтримки малого та середнього бізнесу, а саме 7 грудня 2020 року президент України підписав закони щодо підтримки громадян і бізнесу у період дії карантинних заходів для запобігання поширенню в Україні COVID-19:

1. Закон про соціальну підтримку застрахованих осіб та суб'єктів господарювання на період здійснення обмежувальних протиепідемічних заходів, запроваджених $з$ метою запобігання поширенню на території України гострої респіраторної хвороби COVID-19, передбачає надання одноразової матеріаль- 
ної допомоги у розмірі 8 тис. грн найманим працівникам, які втратили частину заробітної платні внаслідок запровадження карантинних обмежень, та фрізичним особам-підприємцям, які втратили частину доходу внаслідок карантину. Документ передбачає надання одноразової матеріальної допомоги компаніям для виплат найманим працівникам, щоб не скорочувати їх під час дії карантину. Ця норма стосується підприємств, які (на час набуття чинності законом) вимушено скоротили або можуть скоротити тривалість робочого часу працівників через простій у зв'язку 3 впровадженням карантину. Також закон передбачає одноразову компенсацію суб'єктам господарювання 3 метою відшкодування витрат, понесених на сплату єдиного внеску (ЄСВ) на загальнообов'язкове державне соціальне страхування. Компенсації отримають ті компанії, які реально постраждають від запровадження карантинних обмежень. Проте компенсація не надаватиметься, якщо з ЄСВ є заборгованість. Крім того, закон передбачає продовження дії ліцензій компаніям на продаж алкоголю на період карантину, а також протягом трьох місяців після його закінчення. Документи дозвільного характеру продовжують дію на період карантину та протягом трьох місяців після його закінчення. Продовжується й строк дії договорів оренди державного та комунального майна, які закінчуються у період карантину, та протягом одного місяця з дня його закінчення. Не нараховується та не сплачується плата за оренду державного або комунального майна.

2. Закон про внесення змін до Податкового кодексу України та інших законів України щодо соціальної підтримки платників податків на період здійснення обмежувальних протиепідемічних заходів, запроваджених 3 метою запобігання поширенню на території України хвороби COVID-19 передбачає низку податкових стимулів для громадян, малого й середнього бізнесу на період можливого оголошення карантину. Документ передбачає списування податкового боргу платниками податків у разі, якщо сукупний розмір боргу платника за всіма податками та зборами не перевищує 3060 грн. Платники єдиного податку I групи звільняються від сплати цього податку за грудень 2020 року та січень-травень 2021 року. Також до 29 грудня 2021 року відстрочено погашення податкового боргу платників податків - фрізичних осіб, зокрема самозайнятих осіб, що в загальній сумі не перевищує 6800 грн.
3. Закон «Про внесення змін до статті 28 Закону України «Про Державний бюджет України на 2020 рік» розширює перелік напрямків, за якими можуть використовуватися кошти Фонду з боротьби 3 наслідками епідемії коронавірусу. Зокрема, цими коштами може фрінансуватися: одноразова матеріальна допомога громадянам у разі посилення карантину; матеріальна допомога бізнесу для збереження робочих місць; одноразова компенсація бізнесу для сплати ЄСB за найманих працівників [1].

Окрім підписаних президентом законодавчих актів для підтримки малого та середнього бізнесу, до якого відносяться соціальні підприємство в Україні, було запроваджено такі програми:

- «Підтримка малого і середнього бізнесу» - створено портал для підприємців, в якому ви можете знайти каталог програм підтримки, підготовлений Офрісом розвитку МСП, можливості державної підтримки, міжнародних партнерів та банківських установ. Обирайте програму відповідно до потреб вашого бізнесу та виконуєте умови для участі у ній;

- «Підтримка агробізнесу» - Кабінет Міністрів України у державному бюджеті на 2021 рік передбачив 4,7 млрд грн на підтримку агропромислового комплексу. Надання державної допомоги передбачено за програмами: здешевлення придбання сільськогосподарської техніки та обладнання; здешевлення кредитів; розвиток фрермерських господарств; розвиток тваринництва; розвиток садівництва, виноградарства та хмелярства; продовження підтримки за рахунок програми 5-7-9\% (близько $60 \%$ кредитів у межах програми); підтримка та розвиток приватних меліоративних систем, а також надання державних грантів для розвитку державних меліоративних систем.;

- «lнформаційна підтримка бізнесу» - щоб вести справи в умовах карантину, бізнесу пропонується користуватися державними послугами та інформаційними ресурсами online: Covid-19: інфрормаційна підтримка бізнесу https://export.gov.ua/, Реєстрація фрізичної особи підприємця https://diia.gov.ua/services/ reyestraciya-fop, Електронний кабінет платника податків https://cabinet.tax.gov.ua/login, Реєстри Державної податкової служби https://cabinet.tax.gov.ua/registers, Пошук фріскального чека https://cabinet.tax.gov.ual cashregs/check, Пошукмарки акцизногоподатку https://cabinet.tax.gov.ua/registers/mark, Онлайн консультація ДПС https://cabinet.tax.gov.ua/ help/sendlist.html, Відеоуроки користування 
кабінетом платника податків https://tax.gov.ua/ media-tsentr/videogalereya/videouroki/, Державний портал, що справді допоможе у бізнесі https://business.diia.gov.ua/, Програми підтримки підприємців https://www.me.gov.ua/, Єдиний державний портал адміністративних послуг https://my.gov.ua/, Електронніi послуги https://www.kmu.gov.ua/, Платорорма OnFrontiers https://onfrontiers.com/

- «Податкові пресреренції» - для підтримки бізнесу та зниження податкового навантаження на час дії карантину в законодавство внесено наступні зміни: звільнення від нарахування та сплати плати за землю, яка використовується в господарській діяльності, податку на нерухомість за житлові приміщення за березень; обмеження застосування більшості штрасрів за порушення податкового законодавства; мораторій на проведення документальних та фрактичних перевірок (виключення - перевірки щодо відшкодування ПДВ); дозвіл фрізичним особам - підприємцям тимчасово не заповнювати книгу обліку доходів; відтермінування введення РPО для всіх категорій платників податків за спрощеною системою; збільшення лімітів річного доходу для ФОП 1, 2 та 3 груп; звільнення від сплати ПДВ при ввезенні товарів, необхідних для боротьби 3 коронавірусом; спрощення системи обліку продукції та впровадження нульової ставки акцизного податку для державних підприємств, які виробляють дезінфектори на основі спирту; припинення оскаржень рішень контролюючих органів; врахування без обмежень витрат платників Пдв на передачу, в якості внеску в боротьбу 3 коронавірусом, установам охорони здоров'я медикаментів, ліків, обладнання тощо; надання органам місцевого самоврядування права приймати рішення про зміну ставок єдиного податку;

- «Кредитні канікули» - Національний банк України рекомендував банкам ввести особливий пільговий період обслуговування кредитів в період дії карантину для населення та бізнесу. Банки мають декілька варіантів реструктуризації кредитів: 1. Повне або часткове звільнення від сплати тіла кредиту на час карантину з відповідним подовженням позики; 2. Капіталізація відсоткових платежів. Конкретний варіант обирається в індивідуальному порядку після звернення позичальника до банку. Діятиме планова зміна плаваючої відсоткової ставки за договором. Ця заборона розповсюджується на всі кредити фрізичних осіб. Також у цей період заборонено застосовувати штрасри, пені за прострочення виконання [6]. у таблиці 1 ми можемо чітко побачити наслідки, проблеми та шляхи їх подолання впливу на розвиток соціального підприємництва викликані пандемією, також можна зробити висновок, що пандемія COVID-19 значно пригальмувала розвиток соціального підприємництва в Україні загалом.

Згідно 3 Порядком надання та повернення коштів, спрямованих на фрінансування допомоги з часткового безробіття на період карантину, встановленого Кабінетом Міністрів України з метою запобігання поширенню на території України гострої респіраторної хвороби COVID-19, спричиненої коронавірусом SARS-CoV-2, від 22 квітня 2020 р. № 306 введено поняття часткового безробіття на період дії карантину та із подальшими змінами, власникам малого бізнесу, які мають найманих працівників, надається допомога з часткового безробіття. Щоб отримати допомогу, необхідно звернутися до центру зайнятості за місцем реєстрації підприємця як платника ЄСВ та подати необхідні документи [2].

Наша держава намагається здійснити державну фрінансову політику підтримки малого бізнесу, бо це необхідний показник сучасної фрінансової політики держави.

В умовах пандемії COVID-19 у невизначеності опинилися малі підприємства по всьому світу. У Бельгії активність соціальних підприємств знизилась на 85\%, а 21\% бізнесів зовсім перестали працювати. А серед людей 3 інвалідністю, які були у штаті соціальних підприємств, зараз працюють лише 16\%. Це збільшує потребу в соціальних інноваціях, щоб допомогти найбільш вразливим верствам населення. Нижче наведені приклади зарубіжних соціальних підприємств, які намагаються створити рішення для продовження свого існування:

- Fundación Capital в Колумбії - це соціальне підприємство, яке працює над покращенням фінансового життя людей, що живуть у злиднях по всьому світу. Змінив свої чатботи та віртуальних помічників для надання допомоги та інфрормації найбільш вразливим верствам населення щодо офріційної державної інфрормації; кризовий менеджмент; практичні поради та профрілактичні заходи щодо фрізичного та психологічного здоров'я: і фрінансової стійкості - управління фрінансами в кризові періоди;

- AlTibbi - це платформа цифррового охорони здоров'я на Близькому Сході та в Північній Африці, яка має на меті представити надійну, сучасну та спрощену медичну інорор- 
Таблиця 1

Взаємозв'язок проблем та шляхів їх подолання впливу пандемії COVID-19 соціальними підприємствами за участі держави

\begin{tabular}{|c|c|c|c|}
\hline $\begin{array}{l}\text { № } \\
\text { ח/ח }\end{array}$ & $\begin{array}{c}\text { Проблема, викликана } \\
\text { пандемією }\end{array}$ & $\begin{array}{l}\text { Державна } \\
\text { підтримка }\end{array}$ & Що роблять СП \\
\hline 1 & \begin{tabular}{|l|} 
Додаткові витрати \\
(забезпечення \\
працівників засобами \\
особистої гігієни \\
та транспортом) \\
\end{tabular} & \multirow[t]{2}{*}{$\begin{array}{l}\text { Державна програма } \\
\text { «Підтримка малого і } \\
\text { середнього бізнесу» }\end{array}$} & \multirow{2}{*}{$\begin{array}{l}\text { Пошук додаткових джерел фрінансування } \\
\text { (гранти, іноземні інвестиції тощо) } \\
\text { впровадження додаткових фрорматів } \\
\text { роботи та розробки нових товарів та } \\
\text { послуг для оплати заробітної плати та } \\
\text { додаткових витрат }\end{array}$} \\
\hline 2 & $\begin{array}{l}\text { Неможливість виплати } \\
\text { заробітної платні } \\
\text { та скорочення штату }\end{array}$ & & \\
\hline 3 & $\begin{array}{l}\text { Транспортування } \\
\text { працівників підприємств } \\
\text { на роботу та постачання } \\
\text { товарів або сировини } \\
\text { з закордону }\end{array}$ & & $\begin{array}{l}\text { Партнерські стосунки з іншими } \\
\text { соціальними підприємствами в Україні та } \\
\text { закордоном }\end{array}$ \\
\hline 4 & Орендні платежі & $\begin{array}{l}\text { Державна програма } \\
\text { «Кредитні канікули» }\end{array}$ & $\begin{array}{l}\text { Пошук додаткових джерел } \\
\text { фрінансування; платорорма Рatreon } \\
\text { (грошові пожертвування), впровадження } \\
\text { додаткових фрорматів роботи та розробки } \\
\text { нових товарів та послуг }\end{array}$ \\
\hline 5 & $\begin{array}{l}\text { Проблема зі збутом } \\
\text { товарів }\end{array}$ & & $\begin{array}{l}\text { Розвиток діджитал-маркетингу } \\
\text { (налагодження продажів через сайт, } \\
\text { Instagram, Facebook, email), налагодження } \\
\text { кур'єрської служби доставки }\end{array}$ \\
\hline 5 & $\begin{array}{l}\text { Відсутність оборотних } \\
\text { коштів }\end{array}$ & $\begin{array}{l}\text { Державна програма } \\
\text { «Кредитні канікули» }\end{array}$ & $\begin{array}{l}\text { Перегляд бізнес-моделі, пошук додаткових } \\
\text { джерел фінансування (гранти, іноземні } \\
\text { інвестиції, кредитні кошти тощо) }\end{array}$ \\
\hline
\end{tabular}

мацію для користувачів у регіоні на арабській мові. У співпраці з Міністерством охорони здоров'я та за підтримки спонсору Hikma Pharmaceuticals компанія Altibi відкрила спеціальну гарячу лінію Corona, доступну для всіх іорданців. Набравши номер 111, користувачі можуть підключитися до сертисрікованих лікарів. Якщо людина відчуває симптоми, подібні до грипу, або має загальні занепокоєння, вона може отримати медичну оцінку, не виходячи 3 дому, не піддаючи себе чи інших ризику.

- Асоціація безпеки житла для людей похилого віку (SCHSA) - це самофрінансуюче соціальне підприємство та благодійна організація в Гонконзі, яка пропонує цілодобові послуги з особистого догляду та надання невідкладної допомоги людям похилого віку, групам ризику під час цієї пандемії та іншим, хто потребує допомоги. Під час пандемії COVID-19 SCHSA дарує та доставляє маски та відповідні засоби для чищення нестабільним людям похилого віку;

- Crisis Text Line - це глобальна некомерційна організація, яка забезпечує безкоштовне конфріденційне втручання у кризові ситуації за допомогою SMS-повідомлення. Миттю можна було підключитися та отримати підтримку від навченого консультанта в Інтернеті. Послуги організації доступні 24 години на добу щодня по всій території США, Великобританії та Канади;

- Fundación Paraguaya (FP), перша мікрофрінансова установа в Парагваї, розпочала свою діяльність у 1995 році, впроваджуючи новаторську фрінансову грамотність та підприємницьку освіту в Парагваї та адаптуючи методології досягнення молодших класів до малозабезпеченої молоді. Під час пандемії COVID-19 FP розробляє нові способи надання мікрофрінансових позик тим, хто вкрай бідний та вразливий, і йому вдалося охопити понад 3500 сільських банків та 70000 мікропідприємств. Фонд дозволяє позичальникам відкладати свої платежі без будь-яких штрафрних санкцій та пропонує варіанти ресрінансування [4].

У квітні 2020 року був започаткований «Альянс реагування для соціальних підприємців COVID» 60 провідними організаціями соціального сектору, спрямованих на сприяння мобілізації підтримки та підвищення обізнаності про життєво важливу роль цих підприємців у вирішенні кризи та не тільки. У різних якостях члени Альянсу підтримують понад 
50000 соціальних підприємців по всьому світу. У цій програмі для соціальних підприємців COVID-19 члени Альянсу зобов'язуються і закликають своїх однолітків стояти на стороні соціальних підприємців як першочергова допомога у відповіді на кризу в галузі охорони здоров'я та інклюзивного суспільства.

Центр сприяння соціальному підприємництву (CASE) також запустив підтримку для соціальних підприємств Covidcap.com. Це база даних фондів надзвичайної допомоги на суму понад 1 трильйон доларів. Соціальне підприємництво 3 модного тренду перетворюється на незаперечний фракт, на який слід зважати усім секторам суспільства. Соціальні підприємства ще будуть зіштовхуватися 3 нерозумінням і викликами пострадянського прошарку влади. Але якщо соціальні підприємці будуть подавати ініціативу, засвідчувати свої успіхи, заручатися підтримкою громади, то підтримка прийде навіть у кризові часи.

Важливим здобутком 2020 варто вважати заснування Українського соціального венчурного фонду. Він інвестує та підтримує соціальні підприємства, в основі бізнес-моделей яких лежить досягнення соціальних та екологічних змін, шляхом надання допомоги у розмірі до 3000 євро. Варто підкреслити, що його створення $€$ компонентом проєкту «Active Social Entrepreneurship in Ukraine» [5].

Пандемія COVID-19 та криза, спричинена нею, не стали на заваді розвитку соціального підприємництва в Україні. У 2020 було реалізовано спільний проєкт, що покликаний підтримати бізнес-асоціації, громадські організації, організації з підтримки бізнесу та МСП, зміцнюючи спроможність їхньої участі у процесах розвитку соціального підприємництва в Україні - ГО «Простір 500» та Програми USAID «Конкурентоспроможна економіка України» «\#SimpleSE: “Поширення та масштабування успішних моделей соціального підприємництва"». У його рамках засновано онлайн-програму, а також підготовлено та випущено посібник «SimpleSE: Про соціальне підприємництво - просто». В Україні 3 кожним роком збільшується інорормованість та обізнаність населення щодо соціального підприємництва, а разом з цим збільшується і кількість освітніх заходів, онлайн курсів та курсів підвищення кваліфікації, кількість літератури, лише за останні 4 роки було надруковано 10 україномовних посібники 3 соціального підприємництва, це свідчить про невпинний розвиток соціального підприємництва в Україні [9].

Висновки. Проаналізувавши процеси становлення і фрункціонування соціальних підприємств під впливом пандемії та виявивши проблемні аспекти та можливі напрями розвитку соціального підприємництва в Україні під час пандемії можемо прийти до висновку, що звісно, пандемія COVID-19 та карантин позначились на всіх сорерах бізнесу, проте, не зважаючи на це, держава все ще немає чіткого визначення поняття соціальне підприємництво, його часто плутають з благодійною організацією або соціально відповідальним бізнесом, що унеможливлює створення сприятливого бізнес середовища для його розвитку. Досвід зарубіжних країн показує, що не вистачає також державної фрінансової підтримки саме соціальних підприємств, наразі в Україні вона здійснюється виключно у межах підтримки малого та середнього бізнесу.

Пандемія COVID-19 та криза, яку вона спричинила, змусили соціальних підприємців створювати нові бізнес моделі, нові фрормати роботи для соціальних підприємств та бізнесу в цілому. На нашу думку, важливо зосередиться на аспектах, які важливі для виживання соціального підприємства це об'єднання 3 іншими соціальними підприємствами, діджиталізація або взагалі переведення роботи в режим онлайн, створювання нового продукту або послуг, підвищення рівня обізнаності про та популяризація ідей, концепцій соціального підприємництва. Необхідність законодавчого регулювання соціальних підприємств та підтримка з боку держави, необхідне створення сприятливої державної політики, програми підтримки розвитку соціальних підприємств, співпраця соціальних підприємств та представників місцевої влади, державних замовлень для соціальних підприємств, надання пільгових умов оренди приміщень або підтримка у вирішенні інших питань, все це, на нашу думку, це створить сприятливе середовище для розвитку соціальних підприємств в Україні.

\section{СПИСОК ВИКОРИСТАНИХ ДЖЕРЕЛ:}

1. Зміни до Постанови Кабінету Міністрів України від 7 лютого 2018 р. № 107 : Постанова Кабінету Міністрів України від 20 травня 2020 р. № 395. URL: https://zakon.rada.gov.ua/laws/show/395-2020-\%D0\%BF\#Text

2. Про встановлення карантину та запровадження посилених протиепідемічних заходів на території із значним поширенням гострої респіраторної хвороби COVID-19, спричиненої коронавірусом SARSCoV-2: Постанова 
Кабінету Міністрів України від 22 липня 2020 р. № 641. URL: https://www.kmu.gov.ua/npas/pro-vstanovlennyakarantinu-ta-zapr-641

3. Порядок надання та повернення коштів, спрямованих на фрінансування допомоги по частковому безробіттю на період карантину, встановленого Кабінетом Міністрів України з метою запобігання поширенню на території України гострої респіраторної хвороби COVID-19, спричиненої коронавірусом SARS-CoV-2. URL: https://zakon.rada.gov.ua/laws/show/306-2020-\%D0\%BF\#n8 (дата звернення: 19.08.2020).

4. Як врятувати малий бізнес в умовах карантину? URL: https://delo.ua/opinions/jak-vrjatuvati-malijbiznes-vumovah-karantinu-367890/

5. Зелена книга соціального підприємництва в Україні. URL: https://drive.google.com/file/d/1478NOxn3UMD NoqVTbLADr6bAKNvAnWgF/view

6. Коронавірус в Україні Оффіційний інформаційний портал Міністерства охорони здоров'я України. URL: https://covid19.gov.ua/prohramy-pidtrymky-biznesu

7. Sozialunternehmertum: Ein effektives Instrument zur Bewältigung sozialer Herausforderungen in der Ukraine? Bohdan Androshchuk (ChildFund Deutschland e. V., Nürtingen/Berlin), Artem Kornetskyy (Ukrainische Katholische Universität Lwiw/Kiew) Ukraine-Analysen Nr. 210 (13.12.2018). URL: https://www.laender-analysen.de/ukraine/pdf/ UkraineAnalysen210.pdf

8. Соціальне підприємництво: від ідеї до суспільних змін : Посібник / Свинчук А.А., Корнецький А.О., Гончарова М.А., Назарук В.Я., Гусак Н.Є., Туманова А.А. Київ : ТОВ «ПІДПРИЄМСТВО «ВІ ЕН ЕЙ», 2017. 188 с.

9. «Соціальне підприємництво в Україні в часи COVID-19 через призму гендерної рівності» автори проєкту Антонюк Л. та Бочарнікова А. / Дослідження підготовлено завдяки фрінансовій підтримці Європейського Союзу у рамках проєкту стипендіальної програми Eastern Partnership Civil Society Fellowship 2020. URL: http://womensleague.org.ua/Uploads/aadmin/doslidzhennya_sp_covid19_period.pdf?\%24web_only=true\&_ branch_match_id=896483067305150245\&utm_medium=marketing

\section{REFERENCES:}

1. Amendments to the Resolution of the Cabinet of Ministers of Ukraine of February 7, 2018 № 107: Resolution of the Cabinet of Ministers of Ukraine of May 20, 2020 № 395. Retrieved from: https://zakon.rada.gov.ua/laws/ show/395- 2020-\%D0\%BF\#Text

2. On the establishment of quarantine and the introduction of enhanced anti-epidemic measures in the territory with a significant spread of acute respiratory disease COVID-19 caused by coronavirus SARSCoV-2: Resolution of the Cabinet of Ministers of Ukraine of July 22, 2020 № 641. Retrieved from: https://www.kmu.gov.ua/npas/provstanovlennya-karantinu-ta-zap-641

3. Procedure for providing and refunding funds aimed at financing partial unemployment benefits for the period of quarantine established by the Cabinet of Ministers of Ukraine in order to prevent the spread of acute respiratory disease COVID-19 caused by coronavirus SARS-CoV-2 in Ukraine. Retrieved from: https://zakon.rada.gov.ua/laws/ show/306-2020-\%D0\%BF\#n8 (accessed 19 August 2020).

4. How to save small business in quarantine? Retrieved from: https://delo.ua/opinions/jak-vrjatuvati-malijbiznes-v-umovah-karantinu-367890/

5. Green Book of Social Entrepreneurship in Ukraine. Retrieved from: https://drive.google.com/file/d/1478NOxn3UMDNoqVTbLADr6bAKNvAnWgF/view

6. Coronavirus in Ukraine Official information portal of the Ministry of Health of Ukraine. Retrieved from: https://covid19.gov.ua/prohramy-pidtrymky-biznesu

7. Sozialunternehmertum: Ein effektives Instrument zur Bewältigung sozialer Herausforderungen in der Ukraine? Bohdan Androshchuk (ChildFund Deutschland e. V., Nürtingen/Berlin), Artem Kornetskyy (Ukrainische Katholische Universität Lwiw/Kiew) Ukraine-Analysen Nr. 210 (13.12.2018) Retrieved from: https://www.laender-analysen.de/ ukraine/pdf/UkraineAnalysen210.pdf

8. Svinchuk A.A., Kornetsky A.O., Goncharova M.A., Nazaruk V.Ya., Gusak N.Y., Tumanova A.A. (2017) Social education: from ideas to suspicious changes. Posibnik. Kyiv: TOV "PIDPRYMSTVO" VI EN EY ", 188 p.

9. "Social Entrepreneurship in Ukraine in the times of COVID-19 through the prism of gender equality" project authors Antonyuk L. and Bocharnikova A. / The study was prepared with the financial support of the European Union under the Eastern Partnership Civil Society Fellowship 2020. Retrieved from: http://womensleague.org.ua/ Uploads/aadmin/doslidzhennya_sp_covid19_period.pdf?\%24web_only=true\&_branch_match_id=89648306730 5150245\&utm_medium=marketing 